\title{
Methodology for seed germination and vigor tests of Bowdichia virgilioides
}

\author{
Metodología para testes de germinación y vigor \\ de semillas de Bowdichia virgilioides \\ Sidney Saymon Cândido Barreto ${ }^{1}$, Edna Ursulino Alves ${ }^{1}$, Toshik Iarley da Silva ${ }^{2 *}$, \\ Eduardo Vieira Rodrigues ${ }^{1}$, Anderson Carlos de Melo Gonçalves ${ }^{3}$, \\ Marcela de Oliveira Silva ${ }^{1}$, Sueli da Silva Santos Moura ${ }^{1}$
}

\begin{abstract}
Bowdichia virgilioides Kunth., a member of the Fabaceae family, is known as sucupira or paricarana. In addition to its medicinal properties, it has heavy, fibrous wood with ornamental features and high strength. Consequently, the present study aimed to evaluate the effect of the amount of water of the substrate, substrate temperature and the effect of different light regimes on germination and vigor of $B$. virgilioides seeds. In the first experiment, the volumes of water used for wetting the substrate were equivalent to 1.5 , 2.0, 2.5, 3.0 and 3.5 times the weight of the dry substrate, at constant temperatures of 25,30 and $35^{\circ} \mathrm{C}$, and alternating between 20-30 ${ }^{\circ} \mathrm{C}$. In the second experiment, the tested light regimes were white, green, red, far-red and dark light at constant temperatures of 25,30 and $35^{\circ} \mathrm{C}$ and alternated between $20-30{ }^{\circ} \mathrm{C}$. A completely randomized design was used in both experiments, in a $5 \times 4$ factorial model, with four replicates of 25 seeds each. The variables analyzed included percentage, first count and index of germination speed, length and dry mass of roots and shoot length. The seeds of $B$. virgilioides germinated under all light regimes, and classified as neutral photoblastics. The combination of a $30{ }^{\circ} \mathrm{C}$ temperature and volume of water 2.5 times larger than the weight of the dry substrate were shown to be the most appropriate conditions to perform the seed germination test of this species.

Key words: sucupira, temperature, water availability, brightness.
\end{abstract}

\section{RESUMEN}

Bowdichia virgilioides Kunth. perteneciente a la familia Fabaceae, es conocida como sucupira o pariarana. Además de sus propiedades medicinales posee madera pesada, fibrosa, con características decorativas y de gran resistencia. En este contexto. el presente trabajo tuvo como objetivo evaluar el efecto de la cantidad de agua en el sustrato, temperaturas y diferentes regímenes de luz en la germinación y vigor de las semillas de B. virgilioides. En el primer experimento, los volúmenes de agua utilizados para humedecimiento del sustrato fueron equivalentes a 1,5, 2,0, 2,5, 3,0 y 3,5 veces el peso del sustrato seco. en las temperaturas constantes de 25, 30 y $35^{\circ} \mathrm{C}$, y alternada de $20-30^{\circ} \mathrm{C}$. En el segundo experimento. los regímenes de luz probados fueron el de luz blanca, verde, roja, rojo-distante y oscuro continuo, a las temperaturas constantes de 25,30 y $35{ }^{\circ} \mathrm{C}$ y alternada de $20-30{ }^{\circ} \mathrm{C}$. Se adoptó en ambos experimentos el delineamiento enteramente al azar. en factorial $5 \times 4$, con cuatro repeticiones de 25 semillas cada una. Las variables analizadas fueron porcentaje, primer conteo e índice de velocidad de germinación, longitud y masa seca de raíces y parte aérea. Las semillas de $\mathrm{B}$. virgilioides germinan en todos los regímenes de luz, pudiendo ser clasificadas como fotoblásticas neutras y la combinación entre la temperatura de $30^{\circ} \mathrm{C}$ y el volumen de agua de 2,5 veces el peso del sustrato seco es la condición más apropiada para realizar la prueba de germinación de semillas de esta especie.

Palabras claves: sucupira, temperatura, disponibilidad hídrica, brillo.

\section{Introduction}

Tropical forests are rich in genetic diversity. Therefore, they have great potential for use and play a respectable role in global climate balance. The demand for the use of native species in order to restore degraded areas can be verified by the new Forest Code (Law 12.651/12), playing a

1 Federal University of Paraiba, Department of Plant Sciences, Areia, PB, Brazil.

2 Federal University of Viçosa, Department of Plant Sciences, Viçosa, PB, Brazil.

3 Federal University of Roraima, Department of Plant Sciences, Boa Vista, RR, Brazil.

* Corresponding author: toshik.silva@ufv.br

Fecha de Recepción: 06 Marzo, 2019.

Fecha de Aceptación: 30 Abril, 2019. 
role in the preservation of natural resources by maintaining and recovering forest areas. There are several forest species to be implanted in degraded environments, among them, Bowdichia virgilioides Kunth., commonly known as sucupira, sucupirapreta, sucupira-parda, among other popular names (Carvalho, 2008). This species is multiplied through seeds , as in other forests. However, it has been little investigated regarding seed technology.

Considering that the propagation of most forest species is seminiferous, it is essential to study the necessary conditions of germination and the processes made by the used species for reforestation, collaborating with the technology of seedling production and preservation of species. Seed germination is directly influenced by biotic factors (pathogens and dormancy) and abiotic factors (water, light, temperature, oxygen), and it is of great importance to study the techniques and conditions needed to obtain the maximum germination of this species (Brasil, 2009).

The determination of optimum temperature for germination depends on factors such as the evaluated species. seed storage, original region and variety of species, and can be expressed in minimum, optimal and maximum temperatures (Cetnarski Filho and Carvalho, 2009) and in an ideal temperature, which expresses the maximum potential of germination in a shorter period of time for the diversified species (Guedes and Alves, 2011).

Different ranges of temperatures directly influence seeds germination, and can be classified according to species and according to different levels of high and low temperature intensity occurring in the germination process (Andrade et al., 2006). According to Carvalho and Nakagawa (2012), seed imbibition is influenced by temperature, affecting water absorption and bio-metabolic reactions resulting from this physiological process. During the germination test, it is essential that the moisture levels be even in the environment in which the seed will be placed, favoring the germination of the seeds and the development of the seedlings (Oliveira, 2012).

Light is another factor that has either positive or negative implications in the germination of the seeds. Therefore, they can be classified into positive photoblasts (when germination occurs solely in the presence of light), negative photoblasts (when germination is diminished or inhibited under the presence of light) or neutral photoblasts (when germination occurs indifferently to light condition) (Marcos Filho, 2015).

Considering the importance of water availability in the substrate, temperature and lightness for seed germination and seedling formation, the aim of the study is to evaluate the effect of the amount of water in the substrate, as well as the effect of different temperature and different light regimes on germination and seed vigor Bowdichia virgilioides Kunth.

\section{Material and Methods}

\section{Substrate wetting and temperatures}

The experiment was conducted at the Laboratory of Seed Analysis (LSA) of the Agricultural Sciences Center of the Federal University of Paraiba (CCA / UFPB), located at the municipal district of Areia, PB, between the period of January and March 2016, using Bowdichia virgilioides Kunth seeds, obtained from fruits collected from parent plants, located in the experiment municipality. After harvesting, the seeds were taken to LSA for manual seed extraction. The scarification process was carried out with concentrated sulfuric acid for 12 minutes in all experiments described below.

To perform the germination, test the seeds were placed between three "germitest" leaves paper, and then arranged in roll form. Prior to seed distribution, the paper was moistened with different volumes of distilled water, equivalent to $1.5,2.0,2.5,3.0$ and 3.5 times its dry mass, without further addition of water. After the water distribution, the rolls were fed to germinators of the BOD type, regulated for temperature regimes of 25,30 and $35{ }^{\circ} \mathrm{C}$ (constant) and $20-30{ }^{\circ} \mathrm{C}$ (alternating), with photoperiods of $8 / 16$ hours of light and dark, respectively, using daylight fluorescent lamps (4 x $20 \mathrm{~W})$.

\section{Light and temperature regimes}

For this test the germination process was the same as described for the previous experiment. The paper was moistened with the best volume of water obtained in the first experiment. Shortly after the distribution of seeds in the substrate, the rolls were arranged in BOD type germinators, regulated for temperature regimes of 25,30 and $35^{\circ} \mathrm{C}$ (constant) and $20-30^{\circ} \mathrm{C}$ (alternating), with 8/16 eight-hour light 
and dark photoperiod, respectively, using daylight fluorescent lamps (4 x $20 \mathrm{~W})$.

The light regimes evaluated included white light (WL), green (GL), far-red (FRL), red (REL) and absence of light (AL). In order to obtain light waves, cellophane filters were used. For the white light, the rolls were wrapped into two sheets of transparent cellophane filter; for green light, the rolls were wrapped into two green sheets of cellophane filter; to obtain the red light, the rolls were wrapped into two sheets of red cellophane filter, while for far-red the coating was made using two sheets of cellophane filter superimposed one blue and one red. The absence of light was obtained using black plastic bags, using a green safety light during the evaluations.

The evaluation of germination percentage was performed daily once the test was installed, for a 20 day period. It was considered germinated seeds those that emitted primary root and shoot (normal seedlings) (Brasil, 2013). The first germination count was performed together with the germination test and germination rate index (Maguire, 1962). At the end of the test, the length and dry mass of roots and shoot were measured. To determine dry matter, the same seedlings were dried in an oven with forced air circulation, regulated at $65^{\circ} \mathrm{C}$, until reaching constant weight (48 hours) and weighed on a precision scale $(0.001 \mathrm{~g})$.

In both experiments, experimental design was entirely randomized, with treatments distributed in a $5 \times 4$ factorial scheme. In experiment I, the factors included volumes of water and temperature. In experiment II, regimes of light $\mathrm{x}$ temperatures were included, in four replications of 25 seeds for each treatment. The data from both experiments were submitted to analysis of variance. Since the data from the experiment I was quantitative, it was also submitted to polynomial regression analysis, testing the linear and quadratic model, selecting the one with the highest $\mathrm{R}^{2}$. The means obtained in the second experiment were compared by the Tukey's test up to 5\% probability, using the statistical program SISVAR-UFLA (Ferreira. 2011).

\section{Results and Discussion}

\section{Substrate wetting and temperatures}

The germination percentage (GP), first germination count (FGC), germination speed index (GSI), root length (RL) and shoot length (SL) of the seeds of Bowdichia virgilioides submitted to different temperatures in the different volumes of water are shown on Figure 1.

GP, FGC, GSI conformed to regression models. However, they presented means of 79, 83 and $84 \%$, respectively, whereas for seeds submitted to a temperature of $30^{\circ} \mathrm{C}$, the highest percentage of germination $(89 \%)$ was verified with the estimated volume of 2.3 times the dry substrate weight (Figure 1).

The availability of adequate water in the substrate and the ideal temperature are important factors for germination to occur efficiently. Each species requires a specific amount of water and temperature for the efficiency of its germination process, while others have a wide range of requirement. The seeds of $B$. virgilioides are not very demanding in water and temperature, since the germination rates were
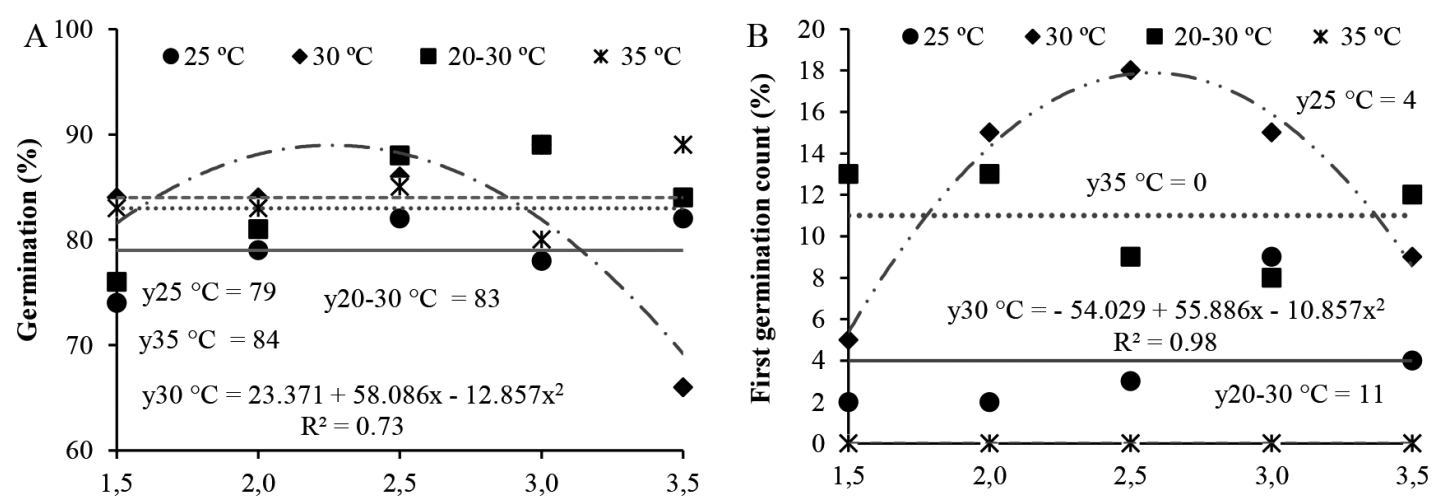

Figure 1. Percentage of germination (a), first germination count (b), germination speed index (c), root length (d) and shoot length (e) of seedlings of $B$. virgilioides from seed submitted to different water contents in the substrate and temperatures. 
high in all the evaluated temperatures, regardless of the used volume of water to moisten the substrate, which is a crucial characteristic that gives a better adjustment, due to its large germination capacity in environments with different water availability and temperatures.

Regarding the vigor, determined by the FGC, the highest average (18\%) was obtained at a temperature of $30^{\circ} \mathrm{C}$, when the substrate was wetted with a volume of water equivalent to 2.5 times its dry weight. At temperatures of 25 and $20-30{ }^{\circ} \mathrm{C}$, there was no adjustment of the data to regression models, whose average values were 4 and $11 \%$, respectively, whereas in the temperature of $35^{\circ} \mathrm{C}$ there was no germination at the first count (Figure 1B). At the appropriate temperature for germination, a higher imbibition speed occurs, with the rapid softening of the tegument and subsequent protrusion of the primary root, which is the ideal condition to trigger the germination process and fix the seedlings in the field (Carvalho and Nakagawa, 2012).

For GSI, it was observed that, for $B$. virgilioides seeds submitted at temperatures of 25 and $35^{\circ} \mathrm{C}$, data did not fit polynomial regression models, with averages of 1.72 and 1.48 , respectively. At a temperature of $30^{\circ} \mathrm{C}$, a quadratic effect was observed, with a higher value (2.2), when an estimated volume of 2.3 times of the dry substrate weight was used. While for seeds submitted at $20-30{ }^{\circ} \mathrm{C}$, positive linear effect with increasing water availability in the substrate was observed (Figure 1C).

Regarding RL from seeds submitted to a temperature of $25{ }^{\circ} \mathrm{C}$, data was not adjusted to regression models, whose mean value was $3.8 \mathrm{~cm}$. When the temperature of $30{ }^{\circ} \mathrm{C}$ was used along with the estimated water volume of 2.3 times the dry substrate weight, the highest value $(5 \mathrm{~cm})$ of root length was obtained, while at a temperature of 20-30 and $35^{\circ} \mathrm{C}$, there was a negative linear effect with increasing water availability in the substrate (Figure 1D).

Regarding the SL data, only water volumes were adjusted to the $30^{\circ} \mathrm{C}$ maximum value $(4.2 \mathrm{~cm})$, when the substrate was moistened with 2.3 times its dry weight (Figure 1E). In tropical species, a larger increase of shoot, followed by the development of the epicotyl is due to the increase of temperature, which accelerates the biochemical reactions and amends the rapid displacement of the seed reserves to the embryonic axis.

Root dry mass data (Figure 2A) did not adjust to regression models, with a mean content of 0.041 ,

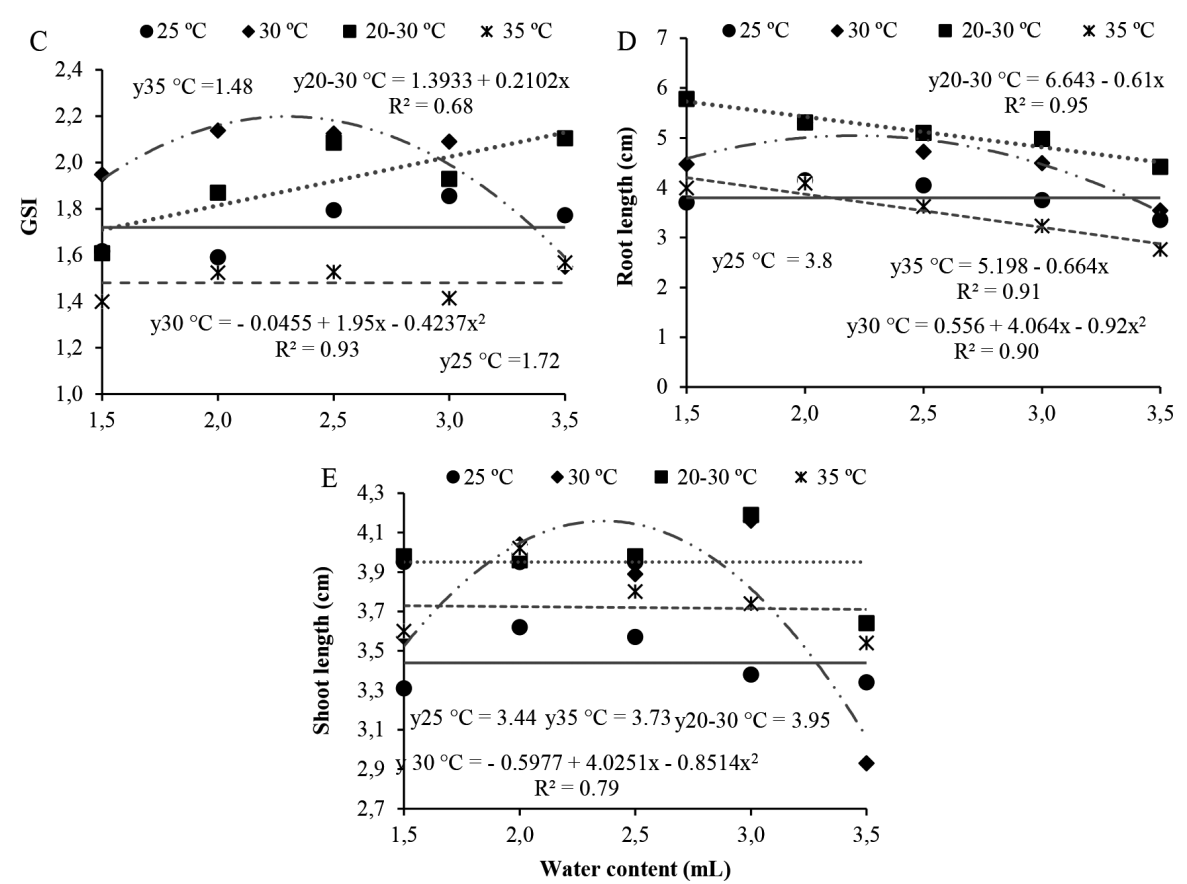

Figure 2. Dry mass of root (a) and shoot (b) of seedlings of $B$. virgilioides from seed submitted to different water contents in the substrate and temperatures. 
$0.038,0.046$ and $0.034 \mathrm{~g}$ at temperatures of 25,30 , $20-30$ and $35^{\circ} \mathrm{C}$, respectively. The dry mass from seedlings submitted to temperatures of 25 and $30^{\circ} \mathrm{C}$ were reduced linearly with increasing volumes of water in the substrate, while temperatures of 20-30 and $35^{\circ} \mathrm{C}$ did not influence the dry mass content of dry of B. virgilioides seedlings (Figure 2B).

Rosseto et al. (2009) had observed that, at a $35{ }^{\circ} \mathrm{C}$ temperature and wetting of 2.5 times the weight of the dry substrate, the seedling dry matter of Parkia pendula (Willd.) was favored. Benth. ex Walp. Dresch et al. (2012) did not observe significant differences in relation to the aforementioned variable in Campomanesia adamantium (Camb.) O. Berg of seeds under moisture (1.5 and 2.5 times the dry paper mass) and temperatures (25.35 and $20-30^{\circ} \mathrm{C}$ ). Results found for shoot and root length, as well as total dry mass of $B$. virgilioides seedlings, show that the higher the water availability in the substrate, the lower the seedling development.

\section{Light and temperature regimes}

In different light regimes and temperatures used, germination percentages of inferior $B$. virgilioides were observed only in combination of green light and constant temperatures of $30^{\circ} \mathrm{C}$ and alternating between $20-30{ }^{\circ} \mathrm{C}$, obtaining high germination percentages under these other conditions (Table 1).

The best range temperature for the germination of most tropical and subtropical species is between 20 and $30^{\circ} \mathrm{C}$ (Borges and Rena, 1993), thus confirming the germination results. In different studies that used other tree species, it was concluded that, for seeds of Crataeva tapia L., the best temperatures were of $20-30{ }^{\circ} \mathrm{C}$, alternating between red and

Table 1. Germination (\%) of B. virgilioides seeds submitted to different temperatures and light regimes.

\begin{tabular}{cclcc}
\hline \multirow{2}{*}{ Light Regimes } & \multicolumn{4}{c}{ Temperatures $\left({ }^{\circ} \mathrm{C}\right)$} \\
\cline { 2 - 5 } & 25 & 30 & $20-30$ & 35 \\
\hline WL & $81 \mathrm{Aa}$ & $92 \mathrm{Aa}$ & $93 \mathrm{Aa}$ & $90 \mathrm{Aa}$ \\
GL & $81 \mathrm{Aa}$ & $78 \mathrm{Ba}$ & $75 \mathrm{Ba}$ & $84 \mathrm{Aa}$ \\
LRE & $81 \mathrm{Aa}$ & $86 \mathrm{Aba}$ & $91 \mathrm{Aa}$ & $82 \mathrm{Aa}$ \\
LRD & $82 \mathrm{Aa}$ & $92 \mathrm{Aa}$ & $92 \mathrm{Aa}$ & $88 \mathrm{Aa}$ \\
AL & $82 \mathrm{Aa}$ & $88 \mathrm{Aba}$ & $92 \mathrm{Aa}$ & $86 \mathrm{Aa}$ \\
\hline
\end{tabular}

Means followed by the same lowercase letter in the line and upper case in the column do not differ up to $5 \%$ by the Tukey test. * White (WL), green (GL), red (REL), far-red (RDL) and absence of light (AL) light. white light conditions, as well as $30^{\circ} \mathrm{C}$ constant under far-red light (Galindo et al., 2012). For seeds of Sideroxylon obtusifolium (Roem \& Schult.), studies from T.D. Penn et al. showed that the best constant temperatures were $25^{\circ} \mathrm{C}$ under green light condition, as well as $30^{\circ} \mathrm{C}$ under white and far-red light (Silva et al., 2014).

The seeds, as germinated both in the absence and presence of light, can be classified as neutral photoblasts, therefore, confirming the classification proposed by Takaki (2005). The evaluated $B$. virgilioides seeds should have fiA phytochrome controlling the germination through very low creep response. Thus, the reserves present in the cotyledons of their seeds appear to be sufficient to guarantee the early development of the seedlings in conditions of low luminosity, since the seeds of this species are small and easily subject to being buried or are located below the litter.

We consider $B$. virgilioides to be a pioneer species when it grows in open areas, disturbed areas, as well as regenerating areas. This is in agreement with Maciel et al. (2008), who reported that pioneer species are the ones that are able to develop at the beginning of ecological succession and whose function would be to rapidly colonize areas that suffered disturbances.

The first seed germination count of $B$. virgilioides was carried out five days after sowing. The germination percentage was higher during constant temperature of $30^{\circ} \mathrm{C}$ in all light regimes, as well as at temperatures of $20-30^{\circ} \mathrm{C}$, alternating under white and dark conditions (Table 2). However, they did not differ statistically from the white, green and far-red light condition at $25^{\circ} \mathrm{C}$, as well as from red and far-red light at alternating temperature of $20-30{ }^{\circ} \mathrm{C}$.

Table 2. First germination count (\%) of B. virgilioides seeds submitted to different temperatures and light regimes.

\begin{tabular}{ccccc}
\hline \multirow{2}{*}{ Light Regimes } & \multicolumn{4}{c}{ Temperatures $\left({ }^{\circ} \mathrm{C}\right)$} \\
\cline { 2 - 5 } & 25 & 30 & $20-30$ & 35 \\
\hline WL & $15 \mathrm{Aab}$ & $25 \mathrm{Aa}$ & $22 \mathrm{Aa}$ & $0 \mathrm{Ab}$ \\
$\mathrm{GL}$ & $13 \mathrm{Aab}$ & $26 \mathrm{Aa}$ & $4 \mathrm{Bb}$ & $0 \mathrm{Ab}$ \\
$\mathrm{REL}$ & $8 \mathrm{Ab}$ & $33 \mathrm{Aa}$ & $21 \mathrm{ABab}$ & $0 \mathrm{Ac}$ \\
FRL & $10 \mathrm{Aab}$ & $26 \mathrm{Aa}$ & $20 \mathrm{ABa}$ & $0 \mathrm{Ab}$ \\
$\mathrm{AL}$ & $7 \mathrm{Abc}$ & $17 \mathrm{Aab}$ & $27 \mathrm{Aa}$ & $0 \mathrm{Ac}$ \\
\hline
\end{tabular}

Means followed by the same lowercase letter in the line and upper case in the column do not differ up to $5 \%$ by the Tukey test. * White (WL), green (GL), red (REL), far-red (RDL) and absence of light (AL) light. 
It was observed that under $35^{\circ} \mathrm{C}$ temperature there was no seed germination in the observed stage, regardless of the light regime adopted.

When analyzing the first germination count, the germination speed was evaluated indirectly, giving that the one with a larger number of seeds germinated in the first count indicate that some seeds germinated faster than others (Carvalho and Nakagawa, 2012). The temperature alternation affects the speed, percentage and uniformity of germination. Thus, the temperature is considered to be optimum, allowing the most efficient combination between the percentage and speed of germination (Marcos Filho, 2015).

At sub-optimal temperatures there is a reduction in the germination speed, resulting in a change of the emergency uniformity, since the seedlings had been exposed for a longer period to adverse factors, becoming susceptible to the attack of pathogens. On the other hand. temperatures above the optimum increase the speed of germination, although only more vigorous seeds were able to germinate (Carvalho and Nakagawa, 2012).

According to Table 3, a higher GSI of $B$. virgilioides seeds at $25^{\circ} \mathrm{C}$ was observed under red, green and white light regimes, as well at temperatures of $20-30$ and $30^{\circ} \mathrm{C}$ for all regimes of light, except for the green light under $20-30^{\circ} \mathrm{C}$ the temperature, whereas, at the $35^{\circ} \mathrm{C}$ temperature, the smaller GSI was observed.

The initial growth of $B$. virgilioides seedlings was evaluated by root length (RL) and shoot (SL). The highest root lengths were obtained at $25{ }^{\circ} \mathrm{C}$ under the green light regime, at $30^{\circ} \mathrm{C}$ under the white light regime, under red and far-red light and at $35^{\circ} \mathrm{C}$ under the green light and absence of light (Table 4).

Table 3. Germination speed index of B. virgilioides seeds submitted to different temperatures and light regimes.

\begin{tabular}{clclc}
\hline \multirow{2}{*}{ Light Regimes } & \multicolumn{4}{c}{ Temperatures $\left({ }^{\circ} \mathrm{C}\right)$} \\
\cline { 2 - 5 } & \multicolumn{1}{c}{25} & 30 & $20-30$ & 35 \\
\hline WL & $2.42 \mathrm{Aa}$ & $2.95 \mathrm{Aa}$ & $2.75 \mathrm{Aa}$ & $1.48 \mathrm{Ab}$ \\
$\mathrm{GL}$ & $2.32 \mathrm{Aab}$ & $2.68 \mathrm{Aa}$ & $1.90 \mathrm{Bbc}$ & $1.34 \mathrm{Ac}$ \\
$\mathrm{LRE}$ & $2.45 \mathrm{Aa}$ & $2.98 \mathrm{Aa}$ & $2.90 \mathrm{Aa}$ & $1.54 \mathrm{Ab}$ \\
$\mathrm{LRD}$ & $2.27 \mathrm{Ab}$ & $3.15 \mathrm{Aa}$ & $2.88 \mathrm{Aab}$ & $1.40 \mathrm{Ac}$ \\
$\mathrm{AL}$ & $2.18 \mathrm{Ab}$ & $2.89 \mathrm{Aa}$ & $3.10 \mathrm{Aa}$ & $1.56 \mathrm{Ab}$ \\
\hline
\end{tabular}

Means followed by the same lowercase letter in the line and upper case in the column do not differ up to $5 \%$ by the Tukey test. * White (WL), green (GL), red (REL), far-red (RDL) and absence of light (AL) light.
Table 4. Length of roots ( $\mathrm{cm}$ ) of B. virgilioides seedlings submitted to different temperatures and light regimes.

\begin{tabular}{clclc}
\hline \multirow{2}{*}{ Light Regimes } & \multicolumn{4}{c}{ Temperatures $\left({ }^{\circ} \mathrm{C}\right)$} \\
\cline { 2 - 5 } & \multicolumn{1}{c}{25} & 30 & $20-30$ & 35 \\
\hline WL & $3.61 \mathrm{ABbc}$ & $5.08 \mathrm{Aa}$ & $3.82 \mathrm{Ab}$ & $2.84 \mathrm{Ac}$ \\
GL & $3.83 \mathrm{Aa}$ & $3.99 \mathrm{Ba}$ & $3.34 \mathrm{Aba}$ & $3.21 \mathrm{Aa}$ \\
LRE & $3.77 \mathrm{Ab}$ & $5.03 \mathrm{Aa}$ & $3.64 \mathrm{Abb}$ & $2.53 \mathrm{Ac}$ \\
LRD & $3.30 \mathrm{ABbc}$ & $5.82 \mathrm{Aa}$ & $3.84 \mathrm{Ab}$ & $2.80 \mathrm{Ac}$ \\
AL & $2.79 \mathrm{Ba}$ & $3.11 \mathrm{Ca}$ & $2.95 \mathrm{Ba}$ & $2.80 \mathrm{Aa}$ \\
\hline
\end{tabular}

Means followed by the same lowercase letter in the line and upper case in the column do not differ up to $5 \%$ by the Tukey test. * White (WL), green (GL), red (REL), far-red (RDL) and absence of light (AL) light.

For seedlings of S. obtusifolium (Roem \& Schult.) T. D. Penn, the highest RL were obtained at $30^{\circ} \mathrm{C}$ while subjected to white light, and at $20-30^{\circ} \mathrm{C}$ under far-red light and at absence of light (Silva et al., 2014), while for Aspidosperma tomentosum Mart seedlings, temperatures of 25 and $30^{\circ} \mathrm{C}$ under the white light regime favored root development (Oliveira et al., 2011).

Growth of the primary root generally varies over a wide temperature range from at least 2 to $5{ }^{\circ} \mathrm{C}$, for seeds of woody species originated from temperate zones, and above $10{ }^{\circ} \mathrm{C}$ for plants from tropical regions (Larcher, 2004) .

The highest shoot lengths (SL) (Table 5) were obtained when $B$. virgilioides seeds were submitted to absence of light at all tested temperatures, as well as in far-red light at temperatures of $20-30^{\circ} \mathrm{C}$. Consequently, it was verified that the seedlings of the species under continuous dark and far-red light $(730 \mathrm{~nm})$ conditions were going through the process of waving, therefore, showing larger length of the shoot.

Table 5. Length of shoot $(\mathrm{cm})$ of $B$. virgilioides seedlings submitted to different temperatures and light regimes.

\begin{tabular}{lllll}
\hline \multirow{2}{*}{$\begin{array}{c}\text { Light } \\
\text { Regimes }\end{array}$} & \multicolumn{4}{c}{ Temperatures $\left({ }^{\circ} \mathrm{C}\right)$} \\
\cline { 2 - 5 } & \multicolumn{1}{c}{25} & \multicolumn{1}{c}{30} & \multicolumn{1}{c}{$20-30$} & \multicolumn{1}{c}{35} \\
\hline $\mathrm{WL}$ & $3.81 \mathrm{Ba}$ & $4.59 \mathrm{Aba}$ & $4.40 \mathrm{ABab}$ & $3.48 \mathrm{Bb}$ \\
$\mathrm{GL}$ & $4.66 \mathrm{ABa}$ & $4.69 \mathrm{Aba}$ & $3.96 \mathrm{Ba}$ & $4.20 \mathrm{Ba}$ \\
$\mathrm{LRE}$ & $4.48 \mathrm{ABa}$ & $4.46 \mathrm{Bab}$ & $4.20 \mathrm{Bab}$ & $3.47 \mathrm{Bb}$ \\
$\mathrm{LRD}$ & $4.51 \mathrm{ABab}$ & $4.53 \mathrm{ABab}$ & $5.21 \mathrm{Aa}$ & $4.0 \mathrm{Bb}$ \\
$\mathrm{AL}$ & $5.17 \mathrm{Aa}$ & $5.37 \mathrm{Aa}$ & $5.15 \mathrm{Aa}$ & $5.26 \mathrm{Aa}$ \\
\hline
\end{tabular}

Means followed by the same lowercase letter in the line and upper case in the column do not differ up to $5 \%$ by the Tukey test. * White (WL), green (GL), red (REL), far-red (RDL) and absence of light (AL) light. 
The highest root dry mass contents (RDM) were obtained when the temperature consisted of $25^{\circ} \mathrm{C}$ under green light, $30^{\circ} \mathrm{C}$ under far red light, $20-30^{\circ} \mathrm{C}$ under white light and $35^{\circ} \mathrm{C}$ in the dark Table 6).

For $C$. tapia $\mathrm{L}$. seedlings, the highest CPA was achieved at $30^{\circ} \mathrm{C}$ under far-red light regime and at 20-30 ${ }^{\circ} \mathrm{C}$ under white light (Galindo et al., 2012). Considering the results obtained for the shoot and primary root length, $B$. virgilioides seedlings are able to develop in a wide range of environmental conditions, which is very important for the natural regeneration of the species.

For seedlings of Clitoria fairchildiana R. A. Howard, the highest RDM was obtained at a temperature of $30^{\circ} \mathrm{C}$, regardless of the light regime tested (Alves et al., 2012). The lowest shoot dry mass contents (SDM) of $B$. virgilioides (Table 7) were observed at constant temperatures of 25 and $35^{\circ} \mathrm{C}$ under continuous dark conditions, not statistically different from each other.

The higher dry mass content obtained in the aforementioned treatments can be explained by the provision of conditions necessary for germination, once the seeds originate seedlings with higher growth rate, due to greater capacity of transformation and supply of reserves of the storage tissues, and greater incorporation of these by the embryonic axis (Dan et al., 1987).

\section{Conclusions}

The water volume combination of 2.5 times the weight of dried substrate in a temperature of $30^{\circ} \mathrm{C}$ is the most appropriate condition for seed germination test of Bowdichia virgilioides Kunth; B. virgilioides seeds germinate under all light conditions, and can
Table 6. Dry mass of roots (g) of B. virgilioides seedlings submitted to different temperatures and light regimes.

\begin{tabular}{lllll}
\hline \multirow{2}{*}{$\begin{array}{c}\text { Light } \\
\text { Regimes }\end{array}$} & \multicolumn{4}{c}{ Temperatures $\left({ }^{\circ} \mathrm{C}\right)$} \\
\cline { 2 - 5 } & \multicolumn{1}{c}{25} & \multicolumn{1}{c}{30} & \multicolumn{1}{c}{$20-30$} & 35 \\
\hline $\mathrm{WL}$ & $0.039 \mathrm{ABab}$ & $0.038 \mathrm{Abab}$ & $0.047 \mathrm{Aa}$ & $0.024 \mathrm{Ab}$ \\
$\mathrm{GL}$ & $0.050 \mathrm{Aa}$ & $0.033 \mathrm{ABbc}$ & $0.035 \mathrm{ABab}$ & $0.019 \mathrm{Ac}$ \\
$\mathrm{LRE}$ & $0.037 \mathrm{ABab}$ & $0.041 \mathrm{Aba}$ & $0.038 \mathrm{ABab}$ & $0.025 \mathrm{Ab}$ \\
$\mathrm{LRD}$ & $0.037 \mathrm{Aba}$ & $0.046 \mathrm{Aa}$ & $0.032 \mathrm{ABab}$ & $0.019 \mathrm{Ab}$ \\
$\mathrm{AL}$ & $0.028 \mathrm{Ba}$ & $0.028 \mathrm{Ba}$ & $0.027 \mathrm{Ba}$ & $0.028 \mathrm{Aa}$ \\
\hline
\end{tabular}

Means followed by the same lowercase letter in the line and upper case in the column do not differ up to $5 \%$ by the Tukey test. * White (WL), green (GL), red (REL), far-red (RDL) and absence of light (AL) light.

Table 7. Dry mass of shoot (g) of B. virgilioides seedlings submitted to different temperatures and light regimes.

\begin{tabular}{lcccc}
\hline \multirow{2}{*}{$\begin{array}{c}\text { Light } \\
\text { Regimes }\end{array}$} & \multicolumn{4}{c}{ Temperatures $\left({ }^{\circ} \mathrm{C}\right)$} \\
\cline { 2 - 5 } & 25 & 30 & $20-30$ & 35 \\
\hline WL & $0.084 \mathrm{Aa}$ & $0.102 \mathrm{Ba}$ & $0.088 \mathrm{Aa}$ & $0.099 \mathrm{Aa}$ \\
$\mathrm{GL}$ & $0.087 \mathrm{Aa}$ & $0.098 \mathrm{Ba}$ & $0.098 \mathrm{Aa}$ & $0.101 \mathrm{Aa}$ \\
$\mathrm{LRE}$ & $0.081 \mathrm{Aa}$ & $0.094 \mathrm{Ba}$ & $0.097 \mathrm{Aa}$ & $0.108 \mathrm{Aa}$ \\
$\mathrm{LRD}$ & $0.079 \mathrm{Aa}$ & $0.115 \mathrm{Ba}$ & $0.102 \mathrm{Aa}$ & $0.100 \mathrm{Aa}$ \\
$\mathrm{AL}$ & $0.061 \mathrm{Ab}$ & $0.331 \mathrm{Aa}$ & $0.102 \mathrm{Ab}$ & $0.083 \mathrm{Ab}$ \\
\hline
\end{tabular}

Means followed by the same lowercase letter in the line and upper case in the column do not differ up to $5 \%$ by the Tukey test. * White (WL), green (GL), red (REL), far-red (RDL) and absence of light (AL) light.

be classified as neutral photoblasts; the constant temperature of $30^{\circ} \mathrm{C}$, under far-red light regime and at a temperature of $20-30{ }^{\circ} \mathrm{C}$, alternating the dark light environment, favors the expression of the vigor, evaluated by the first count and rate of germination.

\section{Literature Cited}

Alves, M.M.; Alves, E.U.; Bruno, R.L.A.; Silva, K.R.G.; SantosMoura, S.S.; Barrozo, L.M.; Araújo, L.R.

2012. Potencial fisiológico de sementes de Clitoria fairchildiana R. A. Howard. - Fabaceae submetidas a diferentes regimes de luz e temperatura. Ciência Rural, 42(12): 2199-2205.

Andrade, A.C.S.; Pereira, T.S.; Fernandes, M.J.; Cruz, A.P.M.; Carvalho, A.S.R.

2006. Substrato, temperatura de germinação e desenvolvimento pós-seminal de sementes de Dalbergia nigra. Pesquisa Agropecuária Brasileira, 41(3): 517-523.

Borges, E.E.L.; Rena, A.B.

1993. Germinação de sementes. In: Aguiar, I.B., PiñaRodrigues, F.C.M.; Figliolia, M B. (Ed.). Sementes florestais tropicais. ABRANTES. Brasília, Brazil. pp 83-135.
BRASIL, Ministério da Agricultura, Pecuária e Abastecimento. 2013. Instruções para análise de sementes de espécies florestais. Brasília, DF: MAPA, 2013. 98 p.

BRASIL. Ministério da Agricultura, Pecuária e Abastecimento. 2009. Regras para análise de sementes. Secretaria de Defesa Agropecuária: MAPA/ACS. Brasília, Brazil. 395 p.

Carvalho, N.M.; Nakagawa, J.

2012. Sementes: ciência, tecnologia e produção. 5.ed. FUNEP. Jaboticabal, Brazil. 590 p.

Carvalho, P.E.R.

2008. Espécies arbóreas brasileiras. Brasília: EMBRAPA Informação Tecnológica; EMBRAPA Florestas. Colombo, Brazil. 593 p.

Cetnarski Filho, R.; Carvalho, R.I.N.

2009. Massa da amostra, substrato e temperatura para teste de germinação de sementes de Eucalyptus dunnii Maiden. Ciência Florestal, 19(3): 257-265. 
Dan, E.L.; Mello, V.D.C.; Wetzel, C.T.; Popinigis, F.; Souza, E.P. 1987. Transferência de matéria seca como método de avaliação do vigor de sementes de soja. Revista Brasileira de Sementes, 9(3): 45-55.

Dresch, D.M.; Scalon, S.P.Q.; Masetto, T.E.; Vieira, M.C. 2012. Germinação de sementes de Campomanesia adamantium (Camb.) O. Berg em diferentes temperaturas e umidades do subtrato. Scientia Forestalis, 40(94): 223-229.

Ferreira, D.F.

2011. Sisvar: A computer statistical analysis system. Ciência e Agrotecnologia, 35(6): 1039-1042.

Galindo, E.A.; Alves, E.U.; Silva, K.B.; Barrozo, L.M.; Santos-

Moura, S.S.

2012. Germinação e vigor de sementes de Crataeva tapia L. em diferentes temperaturas e regimes de luz. Revista Ciência Agronômica, 43(1): 138-145.

Guedes, R.S.; Alves, E.U.

2011. Substratos e temperaturas para o teste de germinação de sementes de Chorisia glaziovii (O. Kuntze). Cerne, 17(4): 525-531.

Larcher, W.

2004. Eco fisiologia vegetal. São Carlos: RiMa, 2004. 531 p.

Maciel, C.D.G.; Poletine, J.P.; Aquino, C.J.R.; Ferreira, D.M.;

Maio, R.M.D.

2008. Composição florística da comunidade infestante em gramados de Paspalum notatum no município de Assis, SP. Planta Daninha, 26(1): 57-64.

Maguire, J.D.

1962. Speed of germination aid in selection and evaluation for seedling emergence and vigor. Crop Science, 2(2): 176-77.
Malavasi, M.M.

1988. Germinação de sementes. In: Piña-Rodrigues, F.C.M. Manual de análise de sementes florestais. Fundação Cargill. Campinas: , Brazil. pp. 25-40.

Marcos Filho, J.

2015. Fisiologia de sementes de plantas cultivadas. Londrina: ABRATES, 2015. 659 p.

Oliveira, A.K.M.; Ribeiro, J.W.F.; Pereira, K.C.L.; Silva, C.A.A. 2011. Germinação de sementes de Aspidosperma tomentosum Mart. (Apocynaceae) em diferentes temperaturas. Revista Brasileira de Biociências, 9(3): 392-397.

Oliveira, O.S.

2012. Tecnologia de sementes florestais: espécies nativas. Imprensa Universitária. Curitiba, Brazil. 406 p.

Rosseto, J.; Albuquerque, M.C.F.; Rondon-Neto, R.M.; Silva, I.C.O.

2009. Germinação de sementes de Parkia pendula (Willd.) Benth. ex Walp. (fabaceae) em diferentes temperaturas. Revista Árvore, 33(1): 47-55.

Silva, K.B.; Alves, E.U.; Oliveira, A.N.P.; Sousa, N.A.; Aguiar, V.A.

2014. Influência da luz e temperatura na germinação de sementes de quixaba. Revista AGROTEC, 35(1): 13-22.

Takaki, M.A.

2005. Luz como fator de estresse na germinação de sementes. In: Nogueira, R.M.C. (Eds.). Estresses ambientais: danos e benefícios em plantas. Recife: Universidade Federal Rural de Pernambuco, Imprensa Universitária. Recife, Brazil. pp. 243-248. 